\title{
Are the social factor one of the reason of violence against women in Palestine?
}

\author{
Allahazimhamide \\ PusatPengajian Pembangunan Sosial,Universiti Utara Malaysia \\ Supervisors: Assoc.Prof.Dr. Noor Azniza Bt. Ishak\& Assoc.ProfDr. JamaldinMustaffa
}

\begin{abstract}
Palestine men constantly face social pressures as well as violence,Males in Palestine have to take major family responsibilities at a very young age as they are taught to take care of their sisters, mothers and female members of their community. As they were raised to be tough and resilient, this social upbringing makes them less tolerant to even petty issues at homes. There have been cases reported on violence against women in Palestine.However, to what extend it has an impact on the Palestinians women and its community is remained to be explored. The issue of violence against women is not given sufficient amount of attention in Palestine either due to negligence or lack in understanding of the relationship between gender and violence.Moreover, in this research the researcher organized the respondent by collect some Palestinian student in University Utara Malaysia they are 11 respondents in the focus group are only male.Generally, the in -depth focus group interview had supported the result of quantitative result with all of the social factor.
\end{abstract}

Keywords: violence, women, social factor, Palestine

The issue of human behavioral problems has been addressed by many researchers by means of a wide range of organization and scientific methods. More particularly, these behavioral problems include maltreatment to women by men which are also shaped by the community attitudes based on various social and cultural norms that engage us with issues of crimes (World Health Organization, 2013).Further, crimes against women can be broadly divided into different categories one of which is violence against women carried out by either individuals or states. Instances of individual violence against women include cases of sexual harassment, rape, domestic violence, prenatal sex selection, forced use of contraceptives, female infanticide, as well as other customary practices such as honor killing, violence related to dowry, forced marriage or marriage by abduction, female genital mutilation. Instances of violence condoned by the state include sexual violence, sexual slavery, war rape, forced abortion and sterilization, and violence by the police and authorities (Prügl, 2013).In order to understand and detect the factors behind men's violence against women, the attitudes of individuals, (social and community) are to be examined first(Hagemann-White, Humphreys, , Tutty, \& Diemer,2014). The attitudes in this context can be defined as the indicators of our thought processes while dealing with issues of crime. Based on our social and cultural norms, attitudes influence the responses to men's violence against women(Holsinger, 1999). Attitudes also determine whether violence is recognized in the society based on which the treatment of the victims as well as the criminals are decided. Since violence against women is mostly committed by men, the attitude of men plays a crucial role in deciphering their accountability and responsibility for violence (Hagemann-White, Humphreys, , Tutty, \& Diemer,2014).

Social and family restrictions prevent women from requesting legal protection. (Ismael,2012). Going through the files of the Public Prosecution till May 2007, there are out an average of 32 cases were submitted daily to the Public Prosecutor in Gaza Strip from battered women against their husbands and other family members(Palestinian Central Bureau of Statistics 2012), but the complaints are withdrawn the following day, before allowing the Public Prosecution to help the women submitting the complaints (Khoury-Kassabri, \& Straus, 2007, July). However, no study has examined and discussed at length the men's attitude about the crimes against women.Palestinian men constantly face social pressures and violence at a very young age. Because of early manly responsibilities in Palestinian society, while most of the organizations are working with the abused women, they do not concentrate on the men in Palestine to change their behavior toward the women (Haj-yahia, 2000). this research will use a focus group is a form of qualitative research in which a group of people are asked about their perceptions, opinions, beliefs, and attitudes towards a product, service, concept, advertisement, idea, or packaging. Questions are asked in an interactive group setting where participants are free to talk with other group members. During this process, the researcher either takes notes or records the vital points he or she is getting from the group. Care should be noted to select members of the group carefully for effective and authoritative responses. 
In the social sciences and urban planning, focus groups allow interviewers to study people in a more natural conversation pattern than typically occurs in a one-to-one interview. In combination with participant observation, they can be used for learning about groups and their patterns of interaction. An advantage is their fairly low cost compared to surveys, as one can get results relatively quickly and increase the sample size of a report by talking with several people at once (Collis\& Hussey, 2013). Another advantage is that they can be used as an occasion for participants to learn from one another as they exchange and build on one another's views, so that the participants can experience the research as an enriching encounter.

\section{RESEARCH OBJECTIVES}

To understand the relationship between the social context and the general experience of the violence against women in Palestine. To exam the general experience of violence against women in Palestine.

\section{RESEARCH METHODOLOGY}

The current research usedqualitative methodto understand the effect of the social factor to violence against women in Palestine.Moreover, in this research the researcher organized the respondent by collect some Palestinian student in University Utara Malaysia they are 11 respondents in the focus group are only male the reason for this deferential because the Palestinian male are more than the female in the camps and some of the women aren't student they are wives with their husbands and their husbands refused to a low to their wives to be in mix group with men. The place of meeting will be inside UUM camps, also the main reasons to Selection to get better and reliable information from thehigh educated expatriate's Palestinian student in UUM they can be good feedback as educated people about the situations in Palestine special in violence against women.

Thus, the focus group interviews will follow many steps and points but in this method the researcher will use Nvivo program as technological program analyzing the qualitative questions, Nvivo allows the researcher to bring order to their data and to identify commonalities and themes. Some scholars suggest that because of the search facility, it provides more rigors, thus strengthening the validity of findings (Welsh, 2002). Whilst the search facilities can provide more rigors, one should not solely rely on these methods. Indeed, I cannot stress this point enough: Nvivo does analyze data; it is the researcher(s) that analyze interpret of the data.

\begin{tabular}{|l|r|}
\hline Section four: the social situations & Probe Questions \\
\hline $\begin{array}{l}\text { What your opinion about the all the social } \\
\text { situations which contribute the crimes against } \\
\text { women in Palestine? }\end{array}$ & $\begin{array}{l}\text { The tribal system hinders the application } \\
\text { of the special regime of crimes against } \\
\text { women }\end{array}$ \\
$\begin{array}{l}\text { - } \\
\text { Palestinian society is macho society } \\
\text { supporting the man against the women }\end{array}$ \\
$\begin{array}{l}\text { The institution of social affairs helps to } \\
\text { reduce crimes against women in } \\
\text { Palestine } \\
\text { The religious institutions influence the } \\
\text { reduction of crimes against women }\end{array}$ \\
\hline
\end{tabular}

\subsubsection{Social factor}

Also this part most of the respondents said many points improved that there is direct relationship between and violence against them some of them mentioned the big family and the effect of the big family on the stability of the couples special between the wife and husband also the big family casing a lot problem made the men did a lot of violence against the women. On the other hand the couple when they are inform the other about their secrets that make the other make problems maybe will cause problems to the couple will create violence between them.

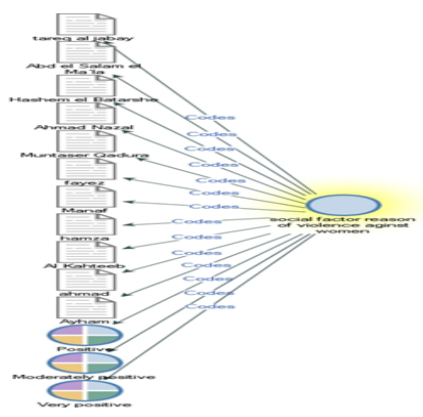


Figure 1.1 social factor

Also this figure showed that all the respondents are agreed that there is relationship between the violence against women and the social factor, for example one of the respondents mentioned that.

'On another level, it is not right to say that violence is limited to the Arabic societies because in Europe as well as in USA, there are statistics which prove that the level of family violence is very high, even though the economical level there is elevated. This also proves that violence has many causes and that the Arabic societies are transforming from one stage into another. We look up to other societies and we try our best to imitate them in order to find ourselves. This does not apply to women only, but men, youth and all the society members as well as the family. People try their best to find themselves. They strive to understand themselves in comparison to others. This stage transforms people from one stage to another in order to express themselves and develop their character'.

According to other respondent 'In Palestine or in the Arabic countries in general there is an understanding of the role of both men and women; the man is in control. With our doors open to the western cultures, our own culture has been affected and made the women to become more daring, which lead to more violence and family problems'.Generally, the in -depth focus group interview had supported the result of quantitative result with all of the social factor.

\section{REFERENCES:}

[1] Collis, J., \& Hussey, R. (2013). Business research: A practical guide for undergraduate and postgraduate students. Palgrave macmillan.

[2] Haj-Yahia, M. M. (2000). Implications of wife abuse and battering for self-esteem, depression, and anxiety as revealed by the second Palestinian national survey on violence against women. Journal of Family Issues, 21(4), 435-463.

[3] Henning, K. R., \&Frueh, B. C. (1996). Cognitive-Behavioral Treatment of Incarcerated Offenders An Evaluation of the Vermont Department of Corrections' Cognitive Self-Change Program. Criminal Justice and Behavior, 23(4), 523-541.

[4] Hagemann-White, C., Humphreys, C., Tutty, L. M., \&Diemer, K. (2014). Overview of current policies on arrest, prosecution, and protection by the police and the justice system as responses to domestic violence. Critical issues on violence against women: International perspectives and promising strategies, 3, 47.

[5] Holsinger, A. M. (1999). Assessing criminal thinking: Attitudes and orientations influence behavior. Corrections Today, 61, 22-25

[6] Ismael, D. A. A. (2012). Palestinian Women in the Cycle of Violence.

[7] Khoury-Kassabri, M., Benbenishty, R., \& Astor, R. A. (2005). The effects of school climate, socioeconomics, and cultural factors on student victimization in Israel. Social Work Research, 29(3), 165180.

[8] Khoury-Kassabri, M., \& Straus, M. (2007, July). Discipline methods used by Arab and Jewish mothers of children age 6 to 9 in Israel. In International Family Violence and Child Victimization Conference. Portsmouth, $\mathrm{NH}$

[9] Palestinian Central Bureau of Statistics (2012): Woman and man Issues and statistics. Ramallah ,Palestine. Referred to http://www.pcbs.gov.ps/Downloads/book1936.pdfCommunication and Applied Communication, 1, 59-67.

[10] Prugl, E, Director (2013): violence against women . Gender and International affairs class 2013. Lecture conducted institute of international.

[11] Steven ,Briggs (2009) important Theories in Criminology: Why People Commit Crime, Part of the Criminology For Dummies Cheat Sheet.

[12] Walters, G. D. (1995). The psychological inventory of criminal thinking styles Part I: reliability and preliminary validity. Criminal Justice and Behavior, 22(3), 307-325.

[13] Walters, G. D. (2005). How many factors are there on the PICTS? Criminal Behaviour and Mental Health, 15, 237-283.

[14] World Health Organization (2013). Crimes against Women Grossly Underestimated, Report Says women. Copyright Health Day.

[15] Yochelson, S., \&Samenow, S. E. (1976). The criminal personality, volume I: A profile for change. Northvale, NJ: Jason Aronson 